\title{
PENGARUH KUALITAS AUDITOR, AUDIT TENURE DAN DEBT DEFAULT TERHADAP PENERIMAAN OPINI AUDIT GOING CONCERN
}

\author{
Oktaviani $^{1}$, Auliffi Ermian Challen ${ }^{2}$ \\ Program StudiAkuntansi Universitas YARSI \\ 'oktavianisiregar@ymail.com, ${ }^{2}$ auliffi.ermian@yarsi.ac.id
}

\begin{abstract}
Abstrack: Going concern audit opinion defined as opinion state by the auditors based on their audit, concludes that substantial doubt exists with regard to the company's ability to continue functioning as a business entity. This study aims to obtain empirical evidence about the effect of auditor quality, audit tenure, and debt default on the acceptance of going concern audit opinion. The sample used in this study is manufacturing companies listed on the Indonesia Stock Exchange and have fulfilled the criteria that existed during the 2013-2017 period, a total of 20 companies. Data analysis techniques using logistic regression.The results of this study empirically prove that auditor quality and the debt default has a positive effect on the acceptance of going concern audit opinion, audit tenure has a negative effect on the acceptance of going concern audit opinion.
\end{abstract}

Key word :Auditor quality, Audit Tenure,Debt Default, Going concern audit opinion

\section{PENDAHULUAN}

Seiring dengan meningkatnya kebutuhan pemakai laporan keuangan terhadap opini auditor ataslaporan audit dalam membuat keputusan yang tepat untuk mengambil keputusan berinvestasi, maka auditor juga perlu melakukan audit mengenai kelangsungan hidup (going concern) suatu entitas, sehingga auditor lebih melakukan pertimbangan dalam memberikan opini audit going concern. Perusahaan akan menerima opini going concern jika terdapat keraguan terhadap keberlanjutan usahanya. Dalam hal ini auditor bertanggung jawab untuk menjelaskan masalah-masalah yang menyebabkan perusahaan tersebut menerima opini going concern karena aporan audit going concern bersifat informatif bagi investor, dimana pengungkapannya mempengaruhi reaksi investor (Syahputra dan Yahya,2017).

Audit tenure didefinisikan sebagai lama hubungan atau keterikatan antara auditor dengan kliennya yang diukur dengan jumlah tahun (Ardiati, 2018). Kecemasan akankehilangan sejumlah fee yang cukup besar akan menimbulkan keraguan bagiauditor untuk menyatakan opini audit going concern, dengan demikian independensi auditor akan terpengaruh dengan lamanya hubungan denganauditee yang sama (Siska,2015).

Debt default didefinisikan sebagai kegagalan debitor (perusahaaan) dalam membayar utang pokok dan atau bunganya pada waktu jatuh tempo (Saputra dan Kustina,2018).Kegagalan suatu perusahaan dalam memenuhi hutang dan atau bunganya merupakan salah satu indikator going concern yang banyak digunakan oleh auditor dalam menilai kelangsungan hidup suatu perusahaan
(Suharsono,2018). Ketika perusahaan tidak mampu membayar hutang dan bunganya dalam jangka waktu yang ditetapkan, hal ini dapat menunjukkan bahwa manajemen gagal di dalam menjalankan operasional perusahaan. Selain itu debt default juga dapat disebabkan karena pihak manajemen perusahaan tidak memperhitungkan rasio keuangan yang ada dan tidak mengetahui bahwa sebenarnya kondisi perusahaan sudah dalam keadaan tidak baik yang dikarenakan nilai hutangnya lebih tinggi dari harta lancarnya. Dengan kondisi seperti ini, kelangsungan hidup usaha suatu entitas bisnis bisa terancam. Hal ini menimbulkan keraguan auditor akan kelangsungan hidup usaha entitas bisnis sehingga dapat membuat auditor untuk mengeluarkan opini audit going concern (Hinarno dan Osesoga,2016).

Berdasarkan uraian dan penjelasan diatas, maka rumusan masalah dalam penelitian ini yaitu: (a) bagaimana pengaruh kualitas auditor terhadap penerimaanopini audit going concern? (b) bagaimana pengaruh audit tenure terhadap penerimaanopini audit going concern? (c) bagaimana pengaruh debt default terhadap penerimaanopini audit going concern?

\section{TINJAUAN PUSTAKA}

Kualitas Auditor

Kualitas audit sebagai kemampuan auditor untuk menemukan kesalahan atau kecurangan dalam sistem akuntansi dan tekanan dari klien untuk menutup buku secara selektif walaupun kecurangan telah ditemukan (DeAngelo, 1981:85). Biasanya mempersepsikan bahwa auditor yang berasal dari KAP besar dan yang memiliki afiliasi dengan KAP Internasional akan memiliki kualitas yang lebih 
tinggi karena auditor tersebut memiliki karakteristik yang dapat dikaitkan dengan kualitas, seperti pelatihan, pengakuan Internasional, dan adanya peer review (Craswell et al dikemukakan oleh Hinanrno dan Osesoga, 2016). KAP yang lebih besar menghasilkan kualitas audit yang lebih baik, serta cenderung untuk lebih berani mengungkapkan masalah yang dialami klien (Tjahjani, 2017).Auditor yang memiliki reputasi yang baik akan cenderung untuk mempertahankan kualitas auditnya agar reputasinya terjaga dan tidak kehilangan klien (Pasaribu, 2015).MenurutArenset. al (2015:29) ada4 kategori ukuran untuk menggambarkan kantor akuntan publik (KAP), yaitu: a) Kantor Internasional Empat Besar ( The Big Four), Kantor Nasional, Kantor Regional dan Kantor Lokal yang Besar, dan Kantor Lokal Kecil.

\section{Audit Tenure}

Audit Tenure adalah jangka waktu bekerjasama yang terjalin diantara KAP (Kantor Akuntan Publik) dengan auditee yang sama. Ketakutan akan kehilangan sejumlah bayaran yang cukup besar akan memicu keraguan bagi auditor untuk memberikan opini audit going concern (Syahputra dan Yahya, 2017).Auditor client tenure merupakan jumlah tahun dimana KAP melakukan perikatan audit pada perusahaan yang sama. Perikatan yang lama dapat menyebabkan berkurangnya independensi KAP (Budiyanto dan Fettry, 2017).

Di Indonesia, ketentuan mengenai audit tenure telah diatur dalam Keputusan Menteri Keuangan Republik Indonesia Nomor. 359/KMK.06/2003 Pasal 2 yaitu Masa Jabatan KAP paling lama 5 tahun berturut-turut. Keputusan Menteri tersebut juga membatasi masa kerja auditor paling lama 3 tahun beturut-turut untuk klien yang sama. Pada tahun 2008, dikeluarkan Peraturan Menteri Keuangan Republik Indonesia Nomor 17/PMK.01/2008 Pasal 3 yaitu tentang pemberian jasa audit umum atas laporan keuangan dari suatu entitas yang dilakukan oleh KAP paling lama 6 tahun berturut-turut dan untuk auditor paling lama 3 tahun berturut-turut. Pada tahun 2015, dikeluarkan peraturan terbaru yaitu Peraturan Pemerintah Republik Indonesia Nomor 20 Tahun 2015 Tentang Praktik Akuntan Publik Pasal 11 mengenai Pembatasan Jasa Audit yaitu Pemberian jasa audit atas informasi keuangan terhadap suatu entitas oleh seorang Akuntan Publik dibatasi paling lama untuk 5 (lima) tahun buku berturut-turut.

\section{Debt Default}

Debt default sebagai kegagalan debitor (perusahaan) dalam membayar utang pokok dan atau bunganya pada waktu jatuh tempo. Sebuah perusahaan dapat dikategorikan dalam keadaan default utangnya bila salah satu kondisi dibawah ini terpenuhi (Chen dan Church, 1992), yaitu: perusahaan tidak dapat atau lalai dalam membayar utang pokok atau bunga, persetujuan perjanjian utang dilanggar, jika pelanggaran perjanjian tersebut tidak dituntut atau telah dituntut kreditor untuk masa kurang dari satu tahun, dan perusahaan sedang dalam proses negosiasi restrukturisasi utang yang jatuh tempo.

Perusahaan yang tidak mampu membayar hutang pokok atau bunganya pada saat jatuh tempo (debt default) maka kemungkinan besar perusahaan akan menerima opini audit going concern (Chen dan Church, 1992). Hal ini menunjukkan bahwa dengan adanya status debt default, semakin besar kemungkinan perusahaan menerima opini audit going concern (Saputra dan Kustina, 2018).

\section{Opini Going Concern}

Menurut IAPI dalam Standar Profesional Akuntan Publik SA 570 Going concern adalah suatu entitas dipandang bertahan dalam bisnis untuk masa depan yang dapat diprediksi. Suatu dalil yang menyatakan bahwa kesatuan usaha akan menjalankan terus operasinya dalam jangka waktu yang cukup lama untuk mewujudkan proyeknya, tanggung jawab serta aktivitas-aktivitasnya yang tidak berhenti (Belkoui, 2007:271). Dalam Standar Profesional Akuntan Publik SA Seksi 341 paragraf 3 (SPAP, 2011) dinyatakan bahwa auditor bertanggungjawab untuk mengevaluasi apakah terhadap kesangsian besar terhadap kemampuan entitas dalam mempertahankan kelangsungan hidupnya dalam periode waktu yang pantas, tidak lebih dari satu tahun sejak tanggal pelaporan keuangan yang sedang diaudit.

\section{PERUMUSAN HIPOTESIS}

\section{Pengaruh Kualitas Auditor Terhadap Penerimaan Opini AuditGoing Concern}

KAP yang lebih besar menghasilkan kualitas audit yang lebih baik, serta cenderung untuk lebih berani mengungkapkan masalah yang dialami klien (Tjahjani, 2017). Auditor yang memiliki reputasi dan nama besar dapat menyediakan kualitas audit yang lebih baik, termasuk dalam mengungkapkan masalah going concern (Nainggolan,2016). Auditor yang memiliki reputasi yang baik akan cenderung untuk mempertahankan kualitas auditnya agar reputasinya terjaga dan tidak kehilangan klien (Pasaribu, 2015).

Hasil Penelitian Khaddafi (2015), Saputra dan Kustina (2018) menunjukkan kualitas auditor berpengaruh positif terhadap penerimaan opini audit going concern. Namun berbeda dengan hasil penelitian Tjahjani (2017) menunjukkan bahwa kualitas auditor berpengaruh negatif terhadap penerimaan opini audit going concern. Sedangkan hasil penelitian Suharsono (2018), Pasaribu (2015), Hinarno dan Osesoga (2016) menunjukkan kualitas 
auditor tidak berpengaruh terhadap penerimaan opini audit going concern. Berdasarkan uraian di atas, maka hipotesis pertama yang diajukan adalah sebagai berikut:

$H_{1}$ : Kualitas Auditor berpengaruh terhadap penerimaan opini audit going concern.

\section{Pengaruh Audit tenure Terhadap Penerimaan Opini AuditGoing Concern}

Audit tenure adalah jangka waktu kerja sama yang terjalin diantara KAP (Kantor Akuntan Publik) dengan auditee yang sama.Ketakutan akan kehilangan sejumlah bayaran yang cukup besar akan memicu keraguan bagi auditor untuk memberikan opini audit going concern (Syahputra dan Yahya, 2017).Semakin lama perikatan audit antara auditor dengan klien menyebabkan independensi auditor berkurang sehingga auditor segan atau lebih sulit untuk memberikan opini going concern kepada kliennya (Analdo, 2017). Ketika hubungan antara auditor dengan klien suatu KAP telah berlangsung bertahun- tahun klien dapat dipandang sebagai sumber pendapatan yang sudah biasa berlangsung terus, yang secara potensial dapat mengurangi independensi KAP (Tandungan dan Mertha, 2016).

Hasil penelitian Ardiati (2018), Saputra dan Kustina (2018), Syahputra dan Yahya (2017), Krissindiastuti dan Rasmini (2016), Nursasi dan Maria (2015) menunjukkan audit tenure berpengaruh negatif terhadap penerimaan opini audit going concern. Namun, berbeda dengan hasil penelitian Tjahjani (2017) menunjukkan audit tenure berpengaruh positif terhadap penerimaan opini audit going concern. Sedangkan hasil penelitian Siska (2015),Budiyanto dan Fettry (2017), menunjukkan audit tenure tidak berpengaruh terhadap penerimaan opini audit going concern.

Berdasarkan uraian di atas, maka hipotesis kedua yang diajukan adalah sebagai berikut:

$\mathrm{H}_{2}$ : Audit tenure berpengaruh terhadap pemberian opini audit going concern.

Pengaruh Debt Default Terhadap Penerimaan Opini AuditGoing Concern

Dalam PSA 30, indikator going concern yang banyak digunakan auditor dalam memberikan keputusan opini audit adalah kegagalan memenuhi pembayaran hutangnya (default)(Imani et.al,
2018).Debt default sebagai kegagalan debitor (perusahaan) untuk membayar hutang pokok dan atau bunganya pada waktu jatuh tempo. Semakin besar suatu perusahaan berada dalam keadaan debt default, maka semakin besar pula kemungkinan diterimanya opini audit going concern (Chen dan Church, 1992). Apabila perusahaan gagal dalam membayar utang (debtdefault) maka kelangsungan usahanya menjadi diragukan, oleh sebab itu kemungkinannya auditor akan memberi opini audit goingconcern (Tjahjani, 2017).

Hasil Penelitian Suharsono (2018), Saputra dan Kustina (2018), Imani et.al (2017), Solikhah (2016), Hinarno dan Osesoga(2016), Khaddafi (2015), Harris dan Merianto (2015) menunjukkan debt default berpengaruh positif terhadap penerimaan opini audit going concern. Sedangkan, hasil penelitian Siska (2015), Tjahjani (2017), menunjukkan debt default tidak berpengaruh terhadap penerimaan opini audit going concern.

Berdasarkan uraian di atas, maka hipotesis ketiga yang diajukan adalah sebagai berikut:

$H_{3}$ : Debt Default berpengaruh terhadap penerimaan opini audit going concern.

\section{METODE PENELITIAN}

Jenis penelitian yang dilakukan adalah penelitian kuantitatif. Penelitian kuantitatifadalah metode penelitian yang berdasarkan pada filsafat positivisme, digunakan untuk meneliti pada populasi atau sampel tertentu, pengumpulan data menggunakan instrumen penelitian, analisis data bersifat statistik, dengan tujuan untuk menguji hipotesis yang telah ditetapkan (Sugiyono, 2012:11).

Populasi dalam perusahaan ini adalah perusahaan manufaktur yang terdaftar di Bursa Efek Indonesia (BEI) tahun 2013-2017, sebanyak 136 perusahaan.Metode penelitian sampel dalam penelitian ini termasuk dalam metode purposive sampling, karena terlebih dahulu sudah ditentukan kriteria-kriteria sample yang akan di ambil. Teknik purposive sampling adalah teknik penentuan sampel dengan pertimbangan tertentu (Sugiyono, 2012:126). Seleksisampelpenelitiandapatdilihat pada tabel 1 berikut ini. 
Tabel 1. Seleksi Sampel Penelitian

\begin{tabular}{|l|c|}
\hline Proses pemilihan sample : & \\
a. Perusahaan yang tidak meyajikan Annual Report dan laporan keuangan \\
yang telah diaudit oleh auditor independen pada tahun 2013-2017 \\
b. Perusahaan tidak menggunakan mata uang Rupiah dalam laporan \\
keuangannya & (27) \\
c. Perusahaan tidak mengalami laba bersih yang negatif sekurang-kurangnya \\
$\begin{array}{l}2 \text { periode laporan keuangan secara berturut-turut selama periode } \\
\text { penelitian 2013-2017 }\end{array}$ \\
Jumlah perusahaan yang tidak memenuhi kriteria & $(80)$ \\
\hline Jumlah Perusahaan yang memenuhi kriteria sampel & \\
\hline Tahun Pengamatan (Tahun) & 20 \\
\hline Jumlah unit analisis & 100 \\
\hline
\end{tabular}

Sumber : diolah penulis, 2018

Variabel dependen pada penelitian ini adalah Opini Audit Going Concern (Y). Pengukuran dilakukan dengan menggunakan variable dummy dimana kode 1 untuk auditee yang menerima opini audit going concern. dan 0 untuk auditee tidak menerima opini audit going concern. Pengukuran ini dapat dilihat pada Laporan Auditor Independen. Kualitas Auditor $\left(\mathrm{X}_{1}\right)$ diukur dengan menggunakan variable dummy dimana kode1 untuk KAP termasuk dalam kategori Big Fourdan 0 untuk KAP tidak termasuk dalam kategori Big Four. Audit Tenure $\left(\mathrm{X}_{2}\right)$ diukur dengan lamanya perikatan antara KAP dengan auditee yang sama, dimulai dengan angka 1(satu) pada tahun pertama dan ditambah dengan angka 1 (satu) untuk tahuntahun berikutnya.Debt Default $\left(\mathrm{X}_{3}\right)$ dikukur dengan menggunakan variable dummy dimana kode 1 untuk status debt defaultdan 0 untuktidak debt default. Pengukuran status debt default dapat dilihat dalamlaporan auditor independen dan ataudalam catatan atas laporan keuangan, dimana data yang digunakan penulis adalah data sekunder.

Teknik pengumpulan data yang digunakan dalam penelitian ini adalah dengan menggunakan metode dokumentasi, yaitu dengan cara mengumpulkan, mencatat, dan mengkaji data sekunder yang berupa laporan keuangan auditan dari perusahaan perbankan yang di publikasikan oleh Bursa Efek Indonesia (BEI) tahun 2013-2017. Teknik pengumpulan data yang digunakan dalam penelitian ini adalah :
1) Kajian pustaka, yaitu dengan mencari literatur yang berhubungan dengan penelitian ini, baik dari buku, jurnal, thesis.

2) Pengumpulan data mengenai perusahaan manufaktur periode 2013-2017 terkait penyampaian laporan keuangan tahunan yang telah diaudit dan annual report.

3) Pengumpulan data melalui media internet, yaitu dengan cara mengunduh laporan keuangan auditan dan laporan tahunan perusahaan melalui website Bursa Efek Indonesia (www.idx.co.id), maupun website lain yang berhubungan dengan penelitian ini.

Penelitian ini menggunakan regresi logistik (logistic regression) dengan bantuan SPSS. Regresi logistik mengabaikan heteroscedacity, artinya variabel dependen tidak memerlukan homoscedacity untuk masing-masing variabel independennya (Gujarati yang dikemukakan oleh Suharsono, 2018). Penelitian ini menggunakan regresi logistik karena variabel dependennya diukur dengan menggunakan variable dummy. Variabel dummy adalah variabel yang menunjukkan keberadaan (presence) atau ketidakberadaan (absence) dari kualitas atau suatu atribut (Ghazali, 2011:65).

\section{Hasil dan Pembahasan}

Hasil Uji Statistik Deskriptif 
Tabel 2. Hasil Analisis Data Deskriptif

\begin{tabular}{|l|r|r|r|r|r|}
\hline & $\mathrm{N}$ & \multicolumn{1}{|c|}{ Minimum } & Maximum & \multicolumn{1}{c|}{ Mean } & \multicolumn{1}{c|}{ Std. Deviation } \\
\hline GC & 100 &, 00 & 1,00 &, 2800 &, 45126 \\
KA & 100 &, 00 & 1,00 &, 1800 &, 38612 \\
AT & 100 & 1,00 & 5,00 & 2,2900 & 1,19168 \\
DD & 100 &, 00 & 1,00 &, 2100 &, 40936 \\
Valid N (listwise) & 100 & & & & \\
\hline
\end{tabular}

Sumber: Hasil Pengolahan Data dengan SPSS 20.00

Hasil statistik deskriptif terhadap penerimaan opini audit going concern menunjukkan nilai minimum sebesar 0 , nilai maksimum sebesar 1 dengan mean 0,28 dan standar deviasi 0,45126. Hal ini menunjukkan bahwa opini audit going concern memiliki sebaran yang besar karena standar deviasi lebih besar dari nilai mean. Nilai mean menunjukkan bahwa data sampel sebanyak 100 terdiri dari $28(0,28 \times 100 \%)$ mendapat opini dengan paragraf going concern, sedangkan sisanya sebanyak 72 (100-28) tidak mendapat opini dengan paragraf penjelas going concern.

Hasil statistik deskriptif terhadap kualitas auditor menunjukkan nilai minimum sebesar 0 , nilai maksimum sebesar 1 dengan mean 0,18 dan standar deviasi 0,38612. Hal ini menunjukkan bahwa data pada variabel kualitas auditor memiliki sebaran yang besar karena standar deviasi menunjukkan nilai yang lebih besar dari pada nilai mean. Nilai mean menunjukkan bahwa data sampel sebanyak 100 terdiri dari $18(0,18 \times 100 \%)$ laporan keuangan diaudit oleh KAP yang berafiliasi dengan Big Four , sedangkan sisanya sebanyak 82 (100-18) laporan keuangan diaudit oleh KAP yang tidak berafiliasi dengan Big Four.

Hasil statistik deskriptif terhadap audit tenure menunjukkan nilai minimum sebesar 1 dan nilai maksimum sebesar 5 dengan mean 2,29 dan standar deviasi 1,19168. Hal ini menunjukkan bahwa data pada audit tenure memiliki sebaran data yang lebih kecil karena standar deviasi menunjukkan nilai yang lebih kecil dari nilai mean. Nilai mean menunjukkan bahwa rata-rata sampel melakukan perikatan audit selama 2,29 tahun.

Hasil statistik deskriptif terhadap debt default menunjukkan nilai minimum sebesar 0 , nilai maksimum sebesar 1 dengan mean 0,21 dan standar deviasi 0,40936. Hal ini menunjukkan bahwa data pada variabel debt default memiliki sebaran yang besar karena standar deviasi lebih besar dari nilai mean. Nilai mean menunjukkan bahwa data sampel $\begin{array}{llll}\text { sebanyak } & 100 \quad \text { terdiri dari } 21\end{array}$ (0,21x100\%)perusahaandenganstatus debt default, sedangkan sisanya sebanyak 79 (100-21) perusahaandenganstatustidakdebt default.

\section{Hasil Uji Koefisien Determinasi}

Besarnya nilai koefisien determinasi pada model regresi logistik dipergunakan untuk menjelaskan seberapa besar variabel independen dapat menjelaskan variabel dependen. Berdasarkan Tabel3,model summary dibawah ini, nilai Nagelkerke $R$ Square $73,8 \%(0,738 \times 100 \%)$ yang berarti variabel dependen (opini going concern) dapat dijelaskan oleh variabel independen (kualitas auditor, debt default dan audit tenure) sebesar persentase tersebut, sedangkan sisanya sebesar $26,2 \%(100 \%-73,8 \%)$ dijelaskan oleh variabelvariabel lain diluar model penelitian.

Tabel 3. Model Summary

\begin{tabular}{|l|r|r|r|}
\hline Step & -2 Log likelihood & Cox \& Snell R Square & Nagelkerke R Square \\
\hline 1 & $46,761^{\mathrm{a}}$ &, 512 &, 738 \\
\hline
\end{tabular}

a. Estimation terminated at iteration number 6 because parameter estimates changed by less than , 001 .

Sumber: Hasil Pengolahan Data dengan SPSS 22.00

Hasil Uji Estimasi Parameter dan Interprestasi 
Tabel 4. Variables in the Equation

\begin{tabular}{|ll|r|r|r|r|r|r|}
\hline & \multicolumn{1}{|c|}{ B } & \multicolumn{1}{|c|}{ S.E. } & \multicolumn{1}{|c|}{ Wald } & \multicolumn{1}{|c|}{ Df } & \multicolumn{1}{|c|}{ Sig. } & \multicolumn{1}{|c|}{$\operatorname{Exp(B)}$} \\
\hline Step 1 $^{\mathrm{a}}$ & KA & 3,621 & 1,066 & 11,539 & 1 &, 001 & 37,360 \\
& AT & $-1,474$ &, 463 & 10,147 & 1 &, 001 &, 229 \\
& DD & 3,950 &, 912 & 18,767 & 1 &, 000 & 51,955 \\
\cline { 2 - 8 } & Constant &, 021 &, 874 &, 001 & 1 &, 981 & 1,021 \\
\hline
\end{tabular}

a. Variable(s) entered on step 1: KA, AT, DD.

Sumber: Hasil Pengolahan Data dengan SPSS 22.00

Dari pengujian dengan regresi logistik diatas maka diperoleh persamaan regresi logistik sebagai berikut :

$\operatorname{Ln} \frac{G C}{1-G C}=0,21+3,621 K A-1,474 A T+3,950 D D$

Berdasarkan hasil regresi logistik maka dapat diinterpretasikan sebagai berikut :

a) Kualitas auditor terhadap penerimaan opini audit going concern

Dari tabel diatas dapat diketahui bahwa X1 (kualitas auditor) menunjukkan tingkat signifikan (p) sebesar 0,001 lebih kecil dari $\alpha=$ 0,05 sehingga $\mathrm{H}_{\mathrm{a} 1}$ diterima dan $\mathrm{H}_{01}$ ditolak artinya variabel kualitas auditor berpengaruh terhadap opini audit going concern. Hasil tabel 4 menunjukkan koefisien betakualitas auditor sebesar 3,621 artinya kualitas auditor berpengaruh positif terhadap penerimaan opini audit going concern.

b) Audit tenure terhadap penerimaan opini audit going concern
Dari tabel diatas dapat diketahui bahwa X2 (audit tenure) menunjukkan tingkat signifikan (p) sebesar 0,001, lebih kecil dari $\alpha=5 \%$ sehingga $\mathrm{H}_{2}$ diterima dan $\mathrm{H}_{02}$ ditolak artinya audit tenure berpengaruh terhadap penerimaan opini audit going concern. Tabel 9 menunjukkan koefisiensi beta audit tenure sebesar -1,474 artinya audit tenure berpengaruh negatif terhadap penerimaan opini audit going concern.

c) Debt default terhadap penerimaan opini audit going concern

Dari tabel diatas dapat diketahu X3 (debt default) menunjukkan tingkat signifikan (p) sebesar 0,000, lebih kecil dari $\alpha=5 \%$ sehingga $\mathrm{H}_{\mathrm{a} 3}$ diterima dan $\mathrm{H}_{03}$ ditolak artinya debt default berpengaruh terhadap penerimaan opini audit going concern. Tabel 4menunjukkan koefisiensi beta debt default sebesar 3,950 artinya debt default berpengaruh positif terhadap penerimaan opini audit going concern.

Hasil Uji Statistik F

Tabel 5. Omnibus Test Of Model Coefficients

\begin{tabular}{|ll|r|r|rr|}
\hline & & Chi-square & Df & Sig. & \\
\hline Step 1 & Step & 71,829 & 3 & &, 000 \\
& Block & 71,829 & 3 &, 000 \\
& Model & 71,829 & 3 & &, 000 \\
\hline
\end{tabular}

Sumber: Hasil Pengolahan Data dengan SPSS 20.00

Tabel omnibus test of model coefficients adalah hasil dari uji $f$ untuk menguji pengaruh variabel independen terhadap variabel dependen secara simultan. Dari tabel tersebut dapat diketahui bahwa nilai signifikasinya $0,00<0,05$ yang artinya $\mathrm{H}_{\mathrm{o}}$ ditolak dan $\mathrm{H}_{\mathrm{a}}$ diterima yaitu variabel independen yang terdiri dari kualitas auditor, audit tenure dan debt default secara simultan (bersama-sama) berpengaruh signifikan terhadap variabel dependen yaitu opini audit going concern.

\section{PEMBAHASAN}

Hasil uji hipotesis pertama menunjukkan kualias auditor berpengaruh positif terhadap penerimaan opini audit going concern. Hasil Penelitian ini sejalan dengan penelitian yang dilakukan Khaddafi (2015), Saputra dan Kustina (2018),yang membuktikan bahwa kualitas auditor berpengaruh positif terhadap penerimaan opini audit going concern. Auditor yang memiliki reputasi baik akan cenderung untuk mempertahankan kualitas auditnya agar reputasinya terjaga dan tidak 
kehilangan klien. Namun, hasil penelitian ini tidak sesuai dengan penelitian yang dilakukan Pasaribu (2015), Hinarno dan Osesoga (2016), Suharsono(2018), yang membuktikan bahwa kualitas auditor tidak berpengaruh terhadap opini audit going concern.Berdasarkan hasil penelitian ini auditor yang berasal dari KAP Big Four memiliki kemampuan lebih dalam menemukan kesalahan atau kecurangan dan cenderung lebih berani dalam pemberian opini audit going concern dibandingkan dengan auditor yang bukan berasal dari KAP Big Four karena KAP yang tergabung dalam Big Four akan berusaha untuk selalu mempertahankan indpendensinya untuk menjaga reputasi, selain itu auditor dari KAP Big Four lebih kuat menghadapi resiko proses pengadilan.

Hasil uji hipotesis kedua menunjukkan audit tenure berpengaruh negatif terhadap penerimaan opini audit going concern. Hasil penelitian ini sesuai dengan hasil penelitian Krissindiastuti dan Rasmini (2016), Syahputra dan Yahya (2017),Ardiati (2018), Saputra dan Kustina (2018). Hasil penelitian ini tidak sesuai dengan penelitian yang dilakukan Nursasi dan Maria (2015), Tjahjani (2017) bahwa audit tenure berpengaruh positif terhadap opini audit going concern. Berdasarkan hasil penelitian ini audit tenure mempengaruhi tingkat independensi auditor dalam memberikan opini audit going concern karena antara auditor dan klien memiliki hubungan yang semakin dekat sehingga memenuhi keinginan klien mungkin menjadi prioritas auditor dan ketakutan akan kehilangan klien membuat semakin kecil kemungkinan auditor untuk memberikan opini audit going concern.

Hasil uji hipotesis ketiga menunjukkan debt default berpengaruh positif terhadap pemberian opini audit going concern. Hasil penelitian ini sesuai dengan hasil penelitian Khaddafi (2015), Harris dan Merianto (2015), Suharsono dan Saputra (2018). Hasil penelitian ini tidak sesuai dengan Tjahjani (2017) dan Hinarno dan Osesoga (2016), Siska (2015), yang menunjukkan hasil debt default tidak berpengaruh terhadap opini audit goingconcern.Berdasarkan hasil penelitian ini perusahaan yang tidak mampu membayar utang pokok atau bunganya pada saat jatuh tempo (debt default) maka kemungkinan besar perusahaan akan menerima opini audit going concern. Semakin tinggi ketidakmampuan perusahaan untuk memenuhikewajibannya, maka semakin besar pula kemungkinan perusahaan untuk menerima opini going. Hasil penelitian ini berarti telah sesuai dengan pernyataan yang tercantum dalamPSA No. 30 tentang kondisi yang perlu dipertimbangkan oleh auditor dalam menilai kelangsungan hidup perusahaan, dimana dalam salah satu pointnya disebutkan tentang kemungkinan suatu perusahaan mengalami kesulitan keuangan yaitu kegagalan dalam memenuhi kewajiban hutangnya atau perjanjian serupa.

\section{Kesimpulan}

a. Kualitas Auditor berpengaruh positif dan signifikan terhadap penerimaan opini audit going concern. Hai ini dapat diartikan bahwa auditor dari KAP Big Four menghasilkan kualitas audit yang lebih baik dan cenderung untuk lebih berani dalam memberikan opini audit going concern.

b. Audit Tenure berpengaruh negatif dan signifikan terhadap penerimaan opini audit going concern . Hal ini dapat diartikan bahwa penerimaan opini audit going concern dipengaruhi oleh lamanya perikatan yang terjalin antara auditor dengan klien. Semakin lama perikatan audit antara auditor dengan klien menyebabkan independensi auditor berkurang sehingga auditor segan atau lebih sulit untuk memberikan opini going concern kepada kliennya.

c. Debt Default berpengaruh positif dan signifikanterhadap penerimaan opini audit going concern. Hal ini dapat diartikan bahwa semakin besar suatu perusahaan berada dalam keadaan debt default sehingga semakin besar pula kemungkinan diterimanya opini audit going concern.

\section{Daftar Pustaka}

Ardiati, Aloysia Yanti. 2018. "Pengaruh Kondisi Keuangan, Audit Tenure, dan Ukuran KAP Terhadap Opini Audit Going Concern Pada Perusahaan Manufaktur yang Terdaftar di BEI Tahun 2012-2016". Jurnal Maksiprenure, Vol. 7, No, 2, hal. 117-128.

Arens dan Loebecke. 1997, “Auditing Pendekatan Terpadu”, Edisi Indonesia. Jakarta : Salemba Empat.

Arens, Alvin A, et.al. 2015. Auditing dan Jasa Assurance, edisi 15. Wibowo Herman dan Perti Tim, penerjemah. Jakarta : Erlangga. Terjemahan dari : Auditing and Assurance Service, Edisi 15.

Azharsyah. 2010. "Tujuan Fiqh Terhadap Penggunaan Konsep Akuntansi Konvensional Dalam Struktur Akuntansi Syariah”. SosioReligia Vol.9,No.3.

Bealkaoi, Ahmed. R. 2007. "Teori Akuntansi, jilid l'. Jakarta:Salemba Empat.

Budiyanto, Junika dan Fettry, Putri Sylvia. 2017. "Pengaruh Ukuran Perusahaan, Audit Lagi, 
Audit Tenure, dab Opini Audit Tahun Sebelumnya Terhadap Pemberian Opini Going Concern (Studi Pada Sektor Pertambangan di Bursa Efek Indonesia)". Kajian Akuntansi, Vol 18, No. 1, pp. 46-59.

Chen, K.C. and Church, B.K. 1992.” Default on Debt Obligations and The Issuance of GoingConcern Report" . Auditing : Journal Practice and Theory, pp. 30-49.

DeAngelo. L.E. 1981. "Auditor Independence, : Low Balling, and Discloser Regulation”. Journal of Accounting and Economics.. August.

Ghozali, Imam. 2011. "Aplikasi Analisis Multivariate dengan program SPSS". Semarang : Badan Penerbit Universitas Diponegoro.

Harahap, Sofyan S. 2012. "Auditing Dalam Perspektif Islam”. Jakarta : Pustaka Quantum.

Harahap, Sofyan S. 2012. "Teori Akuntansi Edisi Revisi”. Jakarta : Pustaka Quantum.

Harris, Randy dan Merianto, Wahyu. 2015. "Pengaruh Debt Default, Disclosure, Opini Audit TahunSebelumnya, Ukuran Perusahaan dan Opinion Shopping TerhadapPenerimaanOpini Audit Going Concern". Diponegoro Journal Of Accounting, Vol. 4, No. 3, Hal. 1-11.

Hinarto, Elia dan Osesoga, Maria Stefani. 2016. "Pengaruh Kualitas Auditor, Kondisi Keuangan, Kepemilikan Perusahaan, Disclocure, pertumbuhan Perusahaan, dan Debt Default Terhadap Penerimaan Opini Going Concern (Studi Pada Perusahaan Manufaktur yang Terdaftar di BEI periode 2012-2014)". Ultima Accounting, Vol. 8, No. 2.

http://www.politeknikindonesia.co.id/2017/03/istiq omah-dalam-bekerja-dan.html

Imani, Galan Khalid, Muhammad Rafki Nazar dan Eddy Budiono. 2017. "The Influence Of Debt Default, Audit Lag, Financial Condition, and Audit Opinion On The Previous Year On Audit Opinion Going Concern". e-Proceeding of Management, Vol. 4, No. 2.

Ikatan Akuntansi Indonesia (IAI). 2017. Standar Akuntansi Keuangan. Jakarta : Ikatan Akuntansi Indonesia

Institut Akuntan Publik Indonesia (IAPI). 2011. Standar Profesional Akuntan Publik : 31 Maret 2011. Jakarta:Salemba Empat.

Khaddafi, Muammar. 2015. "Effect of Debt Defaulty, Audit Quality and Acceptance of Audit Opinion Going Concern in Manufacturing Company in Indonesia Stock Exchange". International Journal of Academic Research in Accounting, Finance and Management Sciences, Vol. 4,No. 11, pp. 80-81
Krissindiastuti, Monica dan Rasmini, Ni Ketut. 2016. "Faktor-faktor yang Mempengaruhi Opini Audit Going Concern". E-Jurnal Akuntasi Universitas Udayana, Vol. 14, No.1

Nursasi, Enggar dan Maria, Evi. 2015. "Pengaruh Audit Tenure, Opinion Shopping, Leverage dan Pertumbuhan Perusahaan Terhadap Penerimaan Opini Audit Going Concern".Jurnal JIBEKA, Vol. 9, No. 1, Hal. 37-43

Pasaribu, Aria Masdiana. 2015. "Pengaruh Kualitas Auditor, Likuiditas, Solvabilitas dan Profitabilitas Terhadap Opini Audit Going Concern Pada Sub Sektor Makanan dan Minuman yang Terdaftar di Bursa Efek Indonesia”. JRAK. Vol. 6, No. 2, hal. 80-92.

Saputra, Evin dan Kustina, Ketut Tanti. 2018. "Analisis Pengaruh Financial Distress, Debt Default, Kualitas Auditor, Auditor Client Tenure, OpinionShopping dan Disclosure Terhadap Penerimaan Opini Audit Going Concern". Jurnal Krisna : Kumpulan Riset Akuntansi, Vol. 10, No. 1.

Siska, Fini Rizki Nanda. 2015. “ Pengaruh Audit Tenure, Disclosure, Ukuran KAP, Debt Default, Opinion Shopping dan Kondisi Keuangan Terhadap Penerimaan Opini Audit Going Concern". Jurnal Ekonomi, Manajemen dan Akuntansi I, Vol. 24, No. 1.

Sugiyono, 2012. "Metode Penelitian Pendidikan Pendekatan Kuantitatif, Kualitatif, dan R\&D”. Bandung : Alfabeta.

Suharsono, Riyanto Setiawan. 2018. "Pengaruh Kualitas Audit, Debt Default dan Pertumbuhan Perusahaan Terhadap Penerimaan Opini Audit Going Concern”. Jurnal Ilmiah Ilmu Akuntansi, Keauangan dan Pajak, Vol. 2, No.1.

Syahputra, Fauzan dan Yahya, M. Rizal. 2017. "Pengaruh Audit Tenure, Audit Delay, Opini Audit Tahun Sebelumnya dan Opinion Shopping Terhadap Penerimaan Opini Audit Going Concern Pada Perusahaan Manufaktur yang Terdaftar di Bursa Efek Indonesia Tahun 20132015". Jurnal Ilmiah Mahasiswa Ekonomi Akuntansi (JIMEKA), Vol. 2, No. 3, hal. 39-47.

Tjahjani, Fera. 2017. "The Acceptan Ce Of Audit Going Concern Opinion On Companies Listed In Indonesia Stock Exchange”. Jurnal Administrasi dan Bisnis, Vol. 11, No. 1. 